\title{
Editorial: Visions for future cities
}

\section{Andreas Brück}

Assistant Professor, Department of Urban and Regional Planning, Technische Universität Berlin, Berlin, Germany

\author{
Angela Million \\ Professor, Department of Urban and Regional Planning, Technische \\ Universität Berlin, Berlin, Germany
}

The future is always in the making, and so are cities. Constant re-imagining and re-making by citizens and the continuous reconfiguration of the built environment make the urban spaces we inhabit a palimpsest of multiple re-imaginations and alternatives. An important part of urban design and planning - though we might perhaps forget about it on the day-to-day basis - is future studies and strategic foresight. The active envisioning of futures for the built environment that will surround us tomorrow is a core topic of urban design and planning. As Marc Augé puts it in his book, The Future, 'The future is essentially obvious, while we are in perpetual doubt over what is to come' (Augé, 2014).

We proposed this themed issue because we are curious to know more about today's visions for the futures of our cities. We wanted to know: what visions of future cities exist today? What alternative scenarios or ideas are there, and/or should be investigated? What are theoretical underpinnings to be explored related to future cities? How does urban envisioning work? Are there new forms of projecting and crafting urban futures?

Urban Design and Planning (UDP) received a great number of reflective and thought-provoking contributions covering multiple areas of planning. They showed an interdisciplinary field of research and action, as our authors have backgrounds in civil engineering, environmental engineering, urban planning, urban policy, art and design. This themed issue took less than a year between the release of the call for papers and writing up this editorial text; a fact that, in our opinion, shows the timeliness and urgency to discuss the futures of our cities and related new approaches in urban planning and design. Hence, overwhelmed with the feedback to this call and the amount of contributions we received for review, we decided to have another issue of UDP on 'Visions for future cities'.

In this first release you will find the following.

- Pollastri et al. (2018) explore how envisioning urban futures can be designed as conversations among different actors (in place of presenting end-product solutions), that engage participants and articulate complexity and criticalities.

- Kwami and Cosgrave (2018) search for points of departure for visionary thinking and approaches to projecting and crafting urban futures from a civil engineering and urban policy perspective.

- Toland and Kilbane (2018) explore retrospectively how physical models have played an important role as envisioning tools for city makers and discuss the potentials of mega-models of Asian cities as tangible tools in today's planning and design practice.

- Powell et al. (2018) showcase a decision-theatre research methodology to reveal how people engage with the built environment and discuss how this could be used to understand future aspirations and desires of urbanites while challenging unrealistic expectations that undermine the viability of new engineering initiatives.

Yet, before all this great research is presented in this issue, we want to briefly fill and inspire your reading with three more thoughts.

First, we want to emphasise how important visions are in general, and how crucial their creation is - especially when it comes to cities and future urbanities - by asking: what are future visions of cities good for?

While there could be many ways to answer this question, in our opinion the future should be seen as a significant renewable resource for humanity. As such, 'a future' is an essential part of our daily lives, and even more, it is a necessity: not thinking about the future, not making predictions, and simply waiting for it to arrive, is escapism. In today's times of multiple crises and transformations - induced by challenging global trends and problematic developments on the local and global level, among other factors - we are confronted with profound change and ever faster acceleration. What Zygmunt Bauman described as Liquid Modernity in the year 2000 not only portrayed very graphically societies' tremendous capacity for transformation, but also highlighted the fast-paced rate at which this occurs (Bauman, 2000). Thinking about the future and envisioning (flexible) solutions to the complex and multifaceted challenges cities encounter is therefore a necessity that should have high priority.

Urban design and planning practice also need to adapt: fast global capitalist economies, the information revolution and 
increased (at least perceived) risk and uncertainty combined seem to lower possibilities for long-term planning, resulting in declining stability and the short-term becoming ever more important. These conditions of fast and constant change paired with a perceived increase in the rate of the passing of time can be either perceived as dangerous and insecure; or as exciting and thrilling. Regardless of how the individual or the collective experiences of time are, when we think of the future we picture something, we project ideas into a scenario or settings. Hence, the future exists in the vision today. One of the problems is: there are too many. Yet it is precisely in this plurality of proposals and envisioned solutions that we might find answers to questions regarding our futures and those of our cities (Brück, 2017). Pluralistic outcomes and solutions grow from the discussion of alternatives and the promotion of a general understanding of a 'Baukultur' (BSBK, 2015), combined with a forward-thinking practice that embraces the future and multiple visions towards it.

Second, we would like to remind of the importance of looking beyond immediate short-term realities and engaging in foresight and visioning by urban designers and planners through asking: why should engineers, planners and urban designer be visionary?

First and foremost: because they can. Marx (quoted by Harvey (2009: p. 236)) said '[w] hat separates the worst of architects from the best of bees is that the architect erects a structure in imagination before realizing it upon the ground'. They (ideally) are trained to envision solutions and have the capacity to communicate their ideas to a broader audience that might get convinced of their virtue. Yet, getting too crazy about the future is often accompanied by fear of being (or becoming) 'out of touch' with reality, and of widening the gap between theory and practice, or between academia and the professional world. In a profession that is heavily involved with unknowns, uncertainties and doubts, fears arise of not meeting the needs of today's planning, engineering and design practices, where one could end up only proposing speculative, hypothetical answers to pressing questions.

Nevertheless, governmental interest in the topic and research programmes like the Foresight Future of Cities project in the UK (which provides policymakers with the evidence, tools and capabilities needed to support policy decisions (GOS, 2016)) or the Initiative Zukunftsstadt in Germany, show that the future of cities is of great concern and that research, design and action in shaping urban futures is paramount to the development of societies, economies and obviously the cities themselves. (The Foresight Future Cities project has been run by the UK Government Office for Science since 2013 - taking a view towards 2065 - as an evidence base and holistic, long-term view futures analysis on the future of UK cities to inform decision- makers; the Initiative Zukunftsstadt was initiated by the German Ministry of Education and Research (BMBF) as an overarching strategic innovation and research agenda bringing together experts from municipalities, science, industry and civil society (BMBF, 2018).) Subsequently, there is a lot of attention being put on scenarios and interpretations of possible futures, including that of cities. Yet, in a rapidly changing world, there is a tendency of discourses on future cities being 'hijacked' by powerful stakeholders and employed through narrowed interpretations to serve their particular interests. For example, current debates on future cities are highly technocratic and are primarily being pushed for and lead by multinational corporations rather than planners or designers - especially when it comes to issues of digitalisation and the 'smart' city (Stollmann et al., 2016; Townsend, 2013). Needless to say, information technology corporations put priority on their products, systems and technologic innovation first, and promote visions of better cities that rely on infrastructure and computerised software and services, with little (if any) regard to compatibility with the contexts in which these 'solutions' are being proposed.

In contrast, urban designers and planners (ideally) bring together knowledge from different fields with people and places: social subjectivities, environmental considerations, resource accessibility and compatibility among the many other components of cities. Besides knowledge of technical issues such as infrastructures and morphologies, some of them have mastered moderation, mediation and negotiation, know principles of co-design and participation, understand the importance of and how to foster bottom-up initiatives and so on. Therefore, they could (and should) lead discourses that follow more holistic approaches for future cities and incorporate parameters like spatial and physical implications on the built environment, or society's role in the process.

And, third, we would like underline and reflect on the importance of visions for future cities in the education of future urban planners and designers, and briefly reflect on the implications for university programmes and the way urban design and planning is (or should) be taught. The question here being: how can universities and the study programs of urban planning and design be places for future thinking?

Looking back at more than 6 years of teaching at TU Berlin we can say that future city visioning has been a major focus in our classes (e.g. summer- and winter-schools like the Green Moabit (Brück and Uttke, 2013)). Students were encouraged to come up with new ways to think about the city beyond what we are providing, and to produce outcomes that may seem futuristic yet are based on educated parameters and have the potential to develop into concrete designs or planning proposals. An example of efforts to bring together policymakers and future urban designers and planners is the cooperative 
project 'Young Professionals Shape the Future' (TU Berlin, 2018). It was conceived in order to pursue current research questions in the field of urban development as a key priority of the National Urban Development Policy, and to promote dialogue between planning faculties in Germany and the Federal Ministry for Building (BMUB). As such, the project opens channels between young and established professionals and works to spark new impetus using the students' ideas on issues relevant for the future of cities in the country.

Although it seems obvious that future thinking would be part of the curriculum of soon-to-be professionals in the crafting of urban tomorrows, this is not always the case. What we learned when talking to colleagues and students is that foresight is not easy to teach, and that visioning is not always part of the curriculum; or at least not the focus. Instead, too often we get caught up in discussions of details and short-term thinking. Nonetheless, urban design and planning education at universities is the place to embrace the future and create understandings on the importance of visions and foresight. Therefore, we should keep in mind and on our agendas that when it comes to education of future urbanists, training students to deal with the future should be pivotal.

Further, education curricula should be constantly updated to include new knowledge and trends: for example, mixing of disciplines, increasing flexibility and adaptability, and promoting regimes of action rather than re-action. We need an urban design and planning education that embraces critical reflection - both logical and speculative - as well as research and methodologies of futurology and critical design, which can be weapons of choice for understanding consequences of, for example, digitalisation, economic policy and other schemes on cities, and of bold engagement in shaping urban tomorrows. As Brück (2017: p. 155) argues, future urban makers should internalise asking divergent questions that follow dynamic inquiry methods and create variations, alternative answers, and scenarios of possible procedures, rather than fixate on static knowledge and 'end products'.

Challenges will continue to rise, old and new ones, and the future of cities is uncertain. Nonetheless, the conditions alone - be they natural, political, technological and so on will not make our cities. Rather, it is the (re)actions of citizens (among them urban designers and planners) that will determine whether cities are able to cope, evolve, succeed or take a second try at success. As Doxiadis (1968: p. 163) noted 50 years ago: we 'talk about the cities of the future, but we seldom discuss the problem of how we should build' those, and thereupon he demanded that '[w]e cannot only predict; we have to decide. [...] We have to start somewhere' (Doxiadis, 1968: p. 171). In the future, urbanites might look back at urbanisms of the 21st century (and their planners) and find our visions, worries, machinations and debates laughable, inaccurate, confused, or foolish. Yet they will have to live in the urban tomorrows we are creating. What is left to us is to try hard to leave a legacy that inspires people to create anew for the renewable future, that helps in finding yet better ways of integrating the countless aspects of life in cities, and one that one can learn from and build on.

\section{REFERENCES}

Augé M (2014) The Future. Verso Books, New York, NY, USA (e-book).

Bauman Z (2000) Liquid Modernity. Polity Press, Cambridge, UK. BMBF (Bundesministerium für Bildung und Forschung) (2018) https:// www.bmbf.de/de/zukunftsstadt-566.html (accessed 19/07/2018).

Brück A (2017) Urban Tomorrows 2030 - Visions \& Counter-Visions for Future Cities. Technische Universität Berlin, Berlin, Germany.

Brück A and Uttke A (2013) Sustainable design and a clothesline: low-tech vs. high-tech solutions. In The "Green Moabit" Urban District Development Concept - International Summer Academy 2012. Senate Department for Urban Development and the Environment, Berlin, Germany, pp. 38-39.

BSBK (Bundesstiftung Baukultur) (2015) Baukultur Report 2014/15. Built Living Spaces of the Future - Focus City. Federal Foundation of Baukultur, Potsdam, Germany. See https://www.bundesstiftungbaukultur.de/sites/default/files/medien/967/downloads/baukulturbericht_2014-15_e.pdf (accessed 19/07/2018).

Doxiadis C (1968) How to build the city of the future. In Man in the City of the Future; a Symposium of Urban Philosophers (Eels R and Walton C (eds)). Macmillan, London, UK, pp. 163-188.

GOS (Government Office for Science) (2016) Future of Cities: Foresight for Cities - A Resource for Policy-makers. GOS, London, UK. See https://www.gov.uk/government/publications/future-of-citiesforesight-for-cities (accessed 19/07/2018).

GOS (2018) https://www.gov.uk/government/collections/future-of-cities (accessed 19/07/2018).

Harvey D (2009) Cosmopolitanism and the Geographies of Freedom. Columbia University Press, New York, NY, USA.

Kwami C and Cosgrave E (2018) Transforming the engineering of cities: 'points of departure' for future visioning. Proceedings of the Institution of Civil Engineers - Urban Design and Planning 171(4): 157-165, https://doi.org/10.1680/jurdp.17.00035.

Pollastri S, Dunn N, Rogers CDF et al. (2018) Envisioning urban futures as conversations to inform design and research. Proceedings of the Institution of Civil Engineers - Urban Design and Planning 171(4): 146-156, https://doi.org/10.1680/jurdp.18.00006.

Powell M, Glendinning S and Dawson R (2018) Drain covers and door steps: decision making and the co-creation of future cities. Proceedings of the Institution of Civil Engineers - Urban Design and Planning 171(4): 177-186, https://doi.org/10.1680/jurdp.17.00033.

Stollmann J, Wolf K, Brück A et al. (eds) (2016) Beware of Smart People! - Redefining the Smart City Paradigm towards Inclusive Urbanism. Universitätsverlag der TU Berlin, Berlin, Germany.

Toland A and Kilbane S (2018) City mega-models as literal and figurative visioning tools. Proceedings of the Institution of Civil Engineers - Urban Design and Planning 171(4): 166-176, https://doi.org/10.1680/jurdp.18.00007.

Townsend A (2013) Smart Cities. Big Data, Civic Hackers, and the Quest for a New Utopia. Norton \& Company, New York, NY, USA.

TU Berlin (2018) http://urbandesign.staedtebau.tu-berlin.de/bmub-bbsryoung-professionals-shape-the-future/ (accessed 19/07/2018). 